\title{
INDEKS PELAYANAN PENDIDIKAN AGAMA PADA SMAN DAN SMKN DI KOTA PALU
}

\section{INDEX OF RELIGIOUS EDUCATION SERVICE AT THE STATE SENIOR HIGH SCHOOLS IN PALU CITY}

\author{
Muhammad Rais \\ Balai Penelitian dan Pengembangan Agama \\ Jl. AP. Pettarani No. 72 Makassar \\ Email: raispuslit2@gmail.com
}

Naskah diterima tanggal 4 Oktober 2017. Naskah direvisi 14 Oktober 2017. Naskah disetujui 30 Oktober 2017.

\begin{abstract}
Abstrak
Artikel ini bertujuan mengukur indeks pelayanan pendidikan agama (Islam, Kristen, Katholik, Hindu dan Buddha) pada satuan pendidikan menengah, tepatnya pada SMAN dan SMKN sebagai sampel sasaran, berkenaan dengan pembelajaran pendidikan agama. Kementerian Agama sejatinya sebagai provider layanan, baik layanan berupa rekruitmen guru, penyediaan sarana dan prasarana, buku teks pegangan guru maupun siswa, dan sumber belajar lainnya, perangkat pembelajaran dan juga kurikulum pendidikan agama. Penelitian ini memanfaatkan metode survey dengan memadukan pendekatan kuantitatif dan kualitatif yang difokuskan pada pengukuran berupa indeks dalam rangka untuk mengetahui mutu layanan pada sembilan unit layanan yang semestinya dipenuhi Kementerian Agama. Hasil penelitian menunjukkan, bahwa tingkat/indeks layanan pendidikan agama di Kota Palu berada pada kategori puas, dengan nilai rata-rata unit layanan atau Indeks Kepuasan Masyarakat dalam hal ini kepala sekolah, peserta didik, dan pendidik rata-rata mutu layanan tersebut terkategori puas (B). Nilai indeks ini mengindikasikan bahwa dalam konteks layanan pendidikan agama pada satuan pendidikan menengah di Kota Palu masih menyisakan masalah yang perlu dicarikan solusi konstruktif, terutama pada aspek: rekruitmen guru, pengadaan buku teks dan sumber belajar lainnya, penguatan kapasitas guru melalui pendidikan dan latihan, bimbingan teknis, dan pemenuhan sarana dan prasarana yang terkait langsung dengan pembelajaran agama di sekolah.
\end{abstract}

Kata kunci: indeks; pelayanan, pendidikan agama Islam, sekolah menengah umum, Palu

\begin{abstract}
This article aims to measure the index of religious education services (Islam, Christian, Catholic, Hindu and Buddhist) in secondary education units, precisely at Senior High School and Vocation Senior Hihg School as the target sample, regarding the learning of religious education. The Ministry of Religious Affairs is actually a service provider, both in the form of teacher recruitment, provision of facilities and infrastructure, textbooks of teachers and students, and other learning resources, learning tools as well as religious teaching curriculum. This study utilizes survey methods with quantitative combined with qualitativeapproach focus on measurement in the form of index in order to know the quality of service in nine service units that should be met by the Ministry of Religious Affairs. The results showed that the level / index of religious education service in Palu City was in the satisfied category, with the average value of service unit or Satisfaction Index in this case principals, learners, and educators the average quality of service is categorized satisfied. The value of this index indicates that in the context of religious education services in secondary education units in Palu City still leaves the problems that need to look for constructive solutions, especially on aspects: recruitment of teachers, procurement of textbooks and other learning resources, strengthening the capacity of teachers through education and training, technical guidance, and the fulfillment of facilities and infrastructure directly related to religious learning in schools.
\end{abstract}

Keywords: index; service; Islamic education; high school, Palu 


\section{PENDAHULUAN}

$\mathrm{P}$ enerapan pendidikan agama-Islam, Kristen, Katholik, Hindu, Buddha, dan Khonghucupada satuan pendidikan menengah sejatinya berpijak pada Peraturan Pemerintah Nomor 19 Tahun 2005 tentang Standar Nasional Pendidikan (SNP) sebagai standar layanan minimum pendidikan, yang meliputi: standar isi, standar proses, standar kompetensi lulusan, standar pendidik dan tenaga kependidikan, standar sarana dan prasarana, standar pengelolaan, standar pembiayaan, dan standar penilaian.

Mengacu pada Peraturan Pemerintah Nomor 55 Tahun 2007 tentang Pendidikan Agama dan Pendidikan Keagamaan disebutkan bahwa persoalan pendidikan agama, tentunya termasuk Islam di dalamnya, menjadi kewenangan Kementerian Agama. Kementerian Agama merupakan lembaga yang paling otoritatif dalam penyelenggaraan PAI ini. Sebagai bagian dari institusi pelayan publik di bidang agama, termasuk pelayanan PAI.

Berkenaan dengan strategi dalam meningkatkan mutu dan pemahaman siswa terhadap ajaran Islam berupa pemberian kesempatanbagisiswauntukmengikutipelatihan Tuntas Baca Tulis Qur'an (TBTQ), mengikuti lomba kreatifitas PAI, penyelenggaraan USBN PAI, serta perluasan materi pengembangan PAI berwawasan kebangsaan. Dan, strategi dalam meningkatkan mutu sumber daya dan sarana prasarana kegiatan belajar mengajar pada sekolah berupa peningkatan kapasitas lembaga pokjawas, adanya lembaga yang melakukan pengembangan pembelajaran dan penilaian kurikulum PAI, pengembangan KKG dan MGMP serta pemberian bantuan saran/ media pembelajaran PAI.

Secara faktual program pelayanan di sektor pendidikan agama yang secara konstitusional menjadi domain otoritas Kementerian Agama sebagaimana dikemukakan di atas, ditengarai belum sepenuhnya berjalan secara optimal sebagaimana yang diharapkan, dan hal itu masih dalam tataran wajar karena baru berjalan beberapa tahun, sementara target capaiannya dipatok hingga tahun 2019.

Salah satu aspek yang masih menjadi pekerjaan rumah institusi keagamaan adalahsebagaimana diakui oleh Dirjen Pendis(Kompas, 04/07/2017) bahwa Indonesia krisis guru pendidikan agama, selain kompetensi, keterpenuhan jumlah guru, khususnya guru PAI masih jauh dari standar atau target yang ideal, Kamruddin Amin mengklaim, bahwa saat ini jumlah guru PAI di sekolah-sekolah umum masih kekurangan sekitar 21.000 orang. Parahnya, karena untuk menutupi kekurangan tersebut, kerapkali pihak sekolah mengambil "jalan pintas" dengan memberdayakan orangorang yang tidak berlatar belakang pendidikan agama, termasuk mereka yang tak mengerti pendidikan agama secara teologis, hal in, lanjut Kamaruddin Amin, membuka ruang bagi kalangan yang ingin mengkapitalisasi untuk tujuan-tujuan yang bersinggungan dengan ekstrimisme. Ia pun berpesan dan mengafirmasi agar pendidikan agama apa pun, termasuk pendidikan agama Islam, harus diajar oleh sarjana pendidikan agama yang memiliki sertifikat pendidikan.

Di tingkat lokal pun, patologi tadi acap dijumpai, Sekretaris Dinas Pendidikan Kota Palu Kamarudin mengatakan, Kota Palu saat ini kekurangan tenaga pengajar khususnya bidang studi keagamaan. Meski telah dilakukan perpanjangan pendaftaran namun jumlah pendaftar masih kurang dari kuota yang telah ditentukan (mediasulawesi. com, diunduh 04/07/2017). Penerimaan guru agama tersebut, berkaitan dengan program walikota Palu tentang pembinaan keagamaan bagi siswa SD Kelas V (lima) melalui tambahan belajar agama tahun 2017. Sementara kuota tenaga pengajar tambahan agama yang akan diterima sebanyak 331 orang yang terdiri dari agama Islam 296 orang, agama Kristen 30 orang, Katholik 2 orang, Hindu 2 orang dan Budha 1 orang.

Selain dimensi SDM, problem yang juga masih mengelayuti pembelajaran PA pada satuan pendidikan menengah adalah aspek kurikulum, yang menurut Muhaimin (2006: 170) masih terpilah-pilah, yang disebut Forgatry sebagai model fragmented, terframentasi antara alquran/hadis, akidah, fiqhi, akhlak dan SKI, dengan model pembelajaran yang fokus pada satu submata pelajaran PAI. Hal ini berimplikasi pada pemahaman, pengamalan dan penghayatan siswa terhadap agama yang fragmented pula.

Untuk melihat sejauhmana performa pelayanan pendidikan agama di Kota Palu, maka penting untuk secara berkala dilakukan 
penelitian indeks berkenaan dengan layanan tersebut. Sebagaiman diafirmasi melalui KEP/25/M.PAN/2/2004,bahwa salah satu upaya untuk meningkatkan kualitas pelayanan publik, tak terkecuali layanan publik di sektor pendidikan agama, sebagaimana diamanatkan dalam Undangundang Republik Indonesia Nomor 25 Tahun 2000 tentang Program Pembangunan Nasional (PROPENAS), perlu disusun indeks kepuasan masyarakat sebagai tolok ukur untuk menilai tingkat kualitas pelayanan. Di samping itu data indeks kepuasan masyarakat akan dapat menjadi bahan penilaian terhadap unsur pelayanan yang masih perfu perbaikan dan menjadi pendorong setiap unit penyelenggara pelayanan untuk meningkatkan kualitas pelayanannya. Maka, di titik inilah, penelitian indeks layanan pendidikan agama pada satuan pendidikan menengah menjadi urgen untuk dilakukan.

Penelitian yang searah dengan riset ini, telah pernah dilakukan Puslitbang Pendidikan Agama dan Keagamaan Balitbang dan Diklat Kementerian Agama, tahun 2016, dengan topik Indeks Pendidikan Agama di SMA, dan menemukan indeks layanan pendidikan agama sebesar 0,81 untuk semua agama di sekolah. Faktor yang menempati urutan paling rendah adalah ketersediaan sarana pembelajaran yang berimplikasi pada keterpenuhan standar proses pembelajaran.

Beranjak dari deskripsi berkenaan dengan arahkebijakan pendidikanagamaberikutstrategi implementasinya yang menjadi kewenangan Kementerian Agama sebagai pelayan publik par excellence di sektor pendidikan agama, dan hambatan-hambatan (barriers) yang menyertai proses penerapan kebijakan tersebut, maka penting dilakukan indeks performa layanan tersebut. Maka, masalah penelitian yang perlu solusi konstruktif melalui penelitian ini adalah: "Sejauhmana indeks layan pendidikan agama pada SMAN dan SMKN di Kota Palu?”

Penelitian ini bertujuan untuk mengukur dan mendeskripsikan tingkat dan atau capaian indeks layanan pendidikan agama (Islam, Kristen, Katholik, Hindu dan Budha) pada satuan pendidikan menengah, yang secara spesifik pada SMAN dan SMKN di Kota Palu, Sulawesi Tengah. Dari data indeks ini diharapkan akan menjadi pijakan kalangan pengambil kebijakan dalam lah ini Ditjen
Pendis via Direktorat Pendidikan Agama Islam, Ditjen Bimas Kristen, Katholik, Hindu dan Budha, termasuk jajarannya di kanwil provinsi dan kemenag Kab/Kota sebagai pihak penerima manfaat secara langsung, juga menjadi bahan assesmen terhadap unsur pelayanan yang masih perlu perbaikan dan menjadi pendorong setiap unit penyelenggara pelayanan untuk meningkatkan kualitas pelayanannya di sektor pendidikan agama pada sekolah-sekolah umum. Bagi publik sendiri, Indeks Kepuasan Masyarakat dapat digunakan sebagai gambaran tentang kinerja pelayanan unit yang bersangkutan.

\section{Tinjauan Pustaka \\ Indeks Layanan Publik}

Dalam penelitian sosial, menurut Sofian Effendi (1989: 104) dikenal beberapa instrumen pengukuran, salah satunya adalah indeks yang kerap dimaknai sama dengan instrument skala, padahal tidak sepenuhnya bisa disejajarkan, meskipun secara sepintas, lanjut Effendi terdapat titik singgung antara keduanya. Sebab dalam penelitian sosial dikembangkan ukuran gabungan yang dipandang lebih akurat mengukur konsep-konsep secara lebih lengkap dan tepat, ukuran gabungan inilah yang selama ini dikenal indeks. Morissan (2014: 80) memosisikan indeks-juga skala-sebagai teknik mengkonstruksi dua tipe ukuran variabel gabungan atau komposit (composite measures of variables). Indeks dan skala, lanjut Marisson, merupakan instrument yang efisien untuk melakukan analisis data. Di samping itu, kedua instrument pengukuran ini merupakan instrument reduksi data yang juga efisien karena memungkinkan kita untuk merangkum beberapa indikator dalam skor angka tunggal, dan tetap mempertahankan detail yang dimiliki setiap variabel.

Dalam buku Kerlinger dikenal istilah indeks relasi (2003: 672). Indeks obyektif ini, bagi Kerlinger dihitung dari statistik agregat, statistik yang diperoleh dari unit-unit sosial, pemerintahan dan organisasi yang lebih besar, dengan menggunakan indikator sosial. Indeks merupakan akumulasi skor untuk tiap pertanyaan. Jadi, kalau suatu indeks terdiri dari lima pertanyaan dan setiap pertanyaan memiliki jenjang skor 1 sampai 3, maka skor indeks berkisar antara 5 dan 15. Adapun langkah-langkah yang ditempuh dalam penyusunan indeks terdiri dari: 1) menyeleksi pertanyaan; 2) hubungan antara pertanyaan/pernyataan, melihat serta mencermati 
hubungan bivariate maupun multivariate dari indikator yang ingin digunakan; dan 3) menentukan skor.

Dalam kerangka pemenuhan akuntabilitas pelayanan publik, Pemerintah telah mengeluarkan kebijakan pendayagunaan aparatur Negara bidang pelayanan public melalui Keputusan Menteri Negara Pendayagunaan Aparatur Negara (MENPAN) Nomor: 81/1995, yang menyebutkan bahwa layanan prima adalah layanan yang memberikan kepuasan pelanggan serta Keputusan Menteri Pendayagunaan Aparatur Negara Nomor Kep/25/M.Pan/2/2004 dan direvisi melalui Peraturan Menteri Aparatur Negara dan Reformasi Birokrasi Nomor 16 Tahun 2014 tentang Pedoman Indeks Kepuasan Masyarakat Unit Pelayanan Instansi Pemerintah. Kebijakan ini dalam merespon tuntutan masyarakat terhadap kualitas pelayanan publik yang semakin meningkat.

\section{Pelayanan Publik}

Konsep pelayanan yang diterjemahkan dari kata sevices, De Vrye (dalam Supriyatno, 2013: 306) mengartikulasikannya menjadi dua makna yang inheren di dalamnya, yaitu"....the attendance of an inferior upon a superior" or "to be useful". Selaras dengan itu, Kotler (dalam Sinambela, 2008: 4-5) memaknai konsep pelayanan sebagai setiap kegiatan yang menguntungkan dalam suatu kumpulan atau kesatuan, dan menawarkan kepuasan, meskipun hasilnya tidak terikat pada suatu produk secara fisik.

Pandji Santoso (2009: 57) mengartikulasikan konsep pelayanan publik sebagai pemberian jasa, baik oleh pemerintah, pihak swasta atas nama pemerintah, ataupun pihak swasta kepada masyarakat, dengan atau tanpa pembayaran guna memenuhi kebutuhan dan atau kepentingan masyarakat. Mastuhu lebih jauh mengaitkan pelayanan publiksebagaiindikatorGoodGovernance, yang dimaknai sebagai prinsip dalam mengatur pemerintahan yang memungkinkan pelayanan publik lebih efisien, sistem pengadilannya bisa diandalkan dan administrasinya bertanggungjawab pada publik (Mastuhu, 2003: 150).

Dalam Kepmenpan Nomor 63/KEP/M. PAN/7/2003 juga ditemukan artikulasi konsep pelayanan publik yang dimaknai sebagai segala kegiatan pelayanan yang dilaksanakan oleh penyelenggara pelayanan publik sebagai upaya pemenuhan kebutuhan penerima pelayanan maupun pelaksanaan ketentuan peraturan perundang-undangan. Sinambela (2008: 5) memaknai pelayanan publik sebagai pemenuhan keinginan dan kebutuhan publik oleh penyelengara Negara.

Pelayanan publik sebagai bagian dari penyelenggaraan Negara, dilihat Eko Prasojo (2009: 80), Mantan Wamenpan RB era SBY, merupakan fungsi dari berbagai faktor. Faktorfaktor yang mempengaruhi pelayanan publik dan penyelenggaraan pemerintahan tersebut antara lain kelembagaan, kepegawaian, proses pengawasan, dan akuntabilitas.Valerie A. Zeithami, et.al (1990) mengklasifikasikan kualitas layanan public pada dua domain, yaitu expected service dan perceived service. Keduanya terbentuk melalui kualitas layanan yang terdiri dari aspek tangible, reability dan seterusnya.

Dilihat dari sisi pola penyelenggaraan, menurut Agus Fanar Syukri, $(2010,17)$ pelayanan publik di Indonesia masih memiliki beberapa kelemahan fundamental, terdiri dari: 1) kurang responsif, kondisi ini terjadi di hampir semua level dan unsur layanan, mulai dari front line staff sampai tingkatan penanggung jawab instansi; 2) kurang informatif; 3) berbagai informasi yang sejatinya disampaikan pada publik, tapi faktanya lambat penyampainnya, bahkan kerap tidak sampai; 4) kurang accessible, layanan kerap jauh dari jangkauan publik; 5) kurang koordinasi, berakibat pada tumpang-tindih kebijakan; 6) terlalu birokratis; 7) kurang berminat mendengar keluhan/ saran/aspirasi publik; dan 8) inefisien.

\section{Pendidikan Agama}

Dalam Konteks pendidikan agama Islam, apabila didekati secara semantik, setidaknya ditemukan beberapa term yang dimaknai sebagai pendidikan, meliputi: ta'dibiyah, ta'lim, tadris, irsyad, tadzkiyah, dan tilawah. Konsep tarbiyah menurut Abdurrahman al-Nahlawi (1998: 30-31) secara derivatif berakar kata: 1) raba-yarbu, yang bermakna bertambah dan atau bertumbuh, sebagai termaktub dalam QS. Al-Rum, 30: 39); 2) rabiyayarba dengan wazan khafiya-yakhfa, yang dapat dimaknai sebagai menjadi besar atau berkembang, sebagaimana yang digunakan Ibn Araby ketika menyatakan:

$$
\text { فمن يكسائلاعنى فإنى ـــــبمكة منزلي وبها ربيت }
$$

Maksudnya: "Jika orang bertanya tentang dirikumaka Mekah adalah tempat kediamanku, dan disitu pulalah aku dibesarkan".

Term yang ketiga, menurut Al-Nahlawi dalam kitabnya, Ushul al-Tarbiyat al-Islamiyah wa Asalibuha, memaknai konsep rabba- yarubbu 
dengan wazan madda-yamuddu-maddan, yang bermakna memperbaiki, menguasai urusan, menuntun, menjaga dan memelihara. Ibn Mandzur dalam kitab lisan al-Arab memaknai konsep rabba, rabbatul al-amr dengan aku memperbaiki atau memperkokoh urusan/perkara itu.

Selain itu, Al-Raghib Al-Ashfahani (2005: 190) dalam kitabnya Mufradat fi Gharibil Quran, memaknai konsep tarbiyah yang secara derivative berakar dari term rabb, dengan memelihara sesuatu sedikit demi sedikit hingga mencapai kesempurnaan (al-Rabb fi al-ashl al-Tarbiyah wa huwa insya al-syai'i, haalan fa haalan ila had al-tamam). Quraish Shihab dalam kitab Tafsirnya, memaknai konsep rabb yang diacu pada arti pengembangan, peningkatan, ketinggian, kelebihan, dan perbaikan (Shihab, 2002: 36).

Sementara Abdurrahman Al-Bani, dalam Madkhal ila Tarbiyah (1397 H), mengemukakan empat elemen yang inheren dalam konsep tarbiyah, meliputi: 1) menjaga dan memelihara fitrah anak hingga menjelang baligh; 2) mengembangkan segenap potensi dan persispan yang beragam; 3) mengarahkan segenap fitrah serta potensi tersebut menuju kepada kebaikan dan kesempurnaan; 4) proses tersebut-sejatinya-dilakukan secara bertahap sebagaimana yang dikemukakan Al-Ashfahani di atas (haalan fa haalan).

Pendidikan agama-Islam, Kristen, Katholik, Hindu, Budha dan Khong hu chu-merupakan salah satu dari tiga mata pelajaran yang wajib diberikan pada setiap jalur, jenis, dan jenjang pendidikan, sebagaiman ditetapkan dalam Pasal 12 UndangUndang Nomor 20 tahun 2003 di atas, bahwa setiap peserta didik pada setiap satuan pendidikan berhak mendapatkan pendidikan agama sesuai dengan agama yang dianutnya dan diajarkan sesuai dengan pendidik yang seagama.

Adapun tujuan yang ingin dicapai melalui pembelajaran mata pelajajaran pendidikan agama pada satuan pendidikan menengah diatas, secara gamblang dikemukakan dalam Undang-Undang Nomor 20 tahun 2003 tentang Sistem Pendidikan Nasional dikemukakan bahwa pendidikan adalah usaha sadar dan terencana untuk mewujudkan suasana belajar dan proses pembelajaran agar peserta didik secara aktif mengembangkan potensi dirinya untuk memiliki kekuatan spiritual, keagamaan, pengendalian diri, kepribadian, kecerdasan, akhlak mulia, serta keterampilan yang diperlukan dirinya, masyarakat, bangsa dan Negara.

\section{METODE PENELITIAN}

Penelitian ini memanfaatkan pendekatan survey, menurut Sevilla, 1993: 76) lazim digunakan untuk mengukur gejala-gejala yang ada tanpa berpretensi untuk meng-eksplore lebih jauh, mengapa gejala-gejala tersebut mengemuka, serta tidak memperhitungkan relasi anta variabel. Tujuan utama pendekatan ini-yang menggunakan instrumen pengukuran berupa indeks-untuk memecahkan masalah yang kini menghambat upaya optimalisasi pelayanan pendidikan agama pada satuan pendidikan menengah (SMAN/SMKN).

Pada umumnya yang merupakan unit analisis dalam penelitian survey adalah individu (Singarimbun dan Effendi, 1989: 3), terdiri dari pendidik, tenaga pendidikan (kepala sekolah) dan peserta didik. Metode survey yang digunakan dalam mengukur indeks layanan pendidikan agama ini, kaitannya dengan populasi dan sampel sepenuhnya mengacu pada pendapat Sevilla (1993: 77) yang membagi survey dalam dua lingkup: sensus dan survey sampel. Klasifikasi ini sekaligus men-counter asumsi yang selama ini yang kerap melakukan pengkutuban antara survey dan sensus, bahwa survey hanya menggunakan sampel sebagai representasi polulasi. Penentuan sampel di tingkat satuan pendidikan dilakukan dengan teknik sensus, mengambil semua SMAN dan SMKN yang tersebar di Kota Palu, pemilihan responden pun dilakukan dengan cara yang sama, populasi sasaran (target population) adalah segenap kepala sekolah serta pendidik yang mengampu mata pelajaran agama di satuan pendidikan menengah tersebut.

Sedangkan pemilihan responden di tingkat peserta didik, akan menggunakan teknik convenience sampling (memilih secara sembarangan) sebagian salah satu teknik dalam sampel non acak. Hal ini absah dilakukan-meskipun tidak ideal dalam metode survey-peneliti sepanjang bisa dijamin bahwa responden masuk dalam kategori populasi sasaran yang telah ditentukan. Teknik ini diklaim Sevilla sebagai sensus hal-hal yang nyata (tangible), jumlah populasi kecil dimana variabel-variabelnya jelas dan kongkret. Hanya kelemahannya, lanjut Sevilla, teknik ini tidak terlalu besar kontribusinya pada khazanah pengetahuan umum di dalam pendidikan.

Kategori jawaban responden terhadap variabel dan segenap indikator yang digunakan untuk mengukur indeks layanan pendidikan agama, terdiri dari:
a. Sangat Puas
dengan nilai skor 
b. Puas

dengan nilai skor

c. Cukup Puas dengan nilai skor

d. Kurang Puas dengan nilai

skor

e. Tidak Puas dengan nilai

skor

Proses pengumpulan data pada penelitian ini akan fokus mengunakan wawancara terstruktur (kuesioner) untuk memperoleh data yang terkait dengan topik dan tujuan penelitian, juga memuat variabel-variabel penelitian dan pernyataanpernyataan yang menjadi indikator-indikator untuk mengukur indeks layanan pendidikan agama, wawancara bebas serta observasi untuk melengkapi data-data yang tidak seluruhnya ter-cover melalui kuesioner. Untuk menelisik lebih dalam problem yang menggelayuti pelayanan PAI pada sekolah sasaran riset, maka dilakukan proses wawancara dengan beberapa responden yang diasumsikan memiliki informasi yang memadai, juga dilengkapi dengan kotak saran dan yang tertera di bagian akhir kuesioner.

Data yang terkumpul pengumpulan data diatas, akan diproses melalui beberapa tahapan, data kemudian diolah untuk mendapatkan data yang siap analisis. Sebagai tahap awal, pemrosesan data atau pengorganisasian data yang lebih dikenal sebagai reduksi data dalam riset kualitatif. Kemudian tahap proses transformasi data melalui penyuntingan maupun proses pengeditan dengan memeriksa kembali data, baik dari sisi kelengkapan, ketepatan, keseragaman maupun relevansi, dilanjtkan proses pengkodean (coding) dan tabulasi), dan puncaknya adalah interpretasi data sebagai bagian dari pemaknaan capaian indeks layanan pendidikan agama.

Secara teknis, pengolahan dan analisis data akan mengacu pada Permenpan nomor 16 tahun 2016 tentang Pedoman Indeks Kepuasan Masyarakat, Nilai Indeks Pelayanan PAI dihitung dengan menggunakan "nilai ratarata tertimbang" masingmasing unsur pelayanan. Dalam penghitungan indeks kepuasan publik terhadap unsur-unsur pelayanan yang dikaji, setiap unsur pelayanan memiliki penimbang yang sama dengan rumus sebagai berikut:

Bobot nilai rata - rata tertimbang $=\frac{\text { jumlah Bobot }}{\text { Jumah } \text { Unsur }}=\frac{1}{9}=0,11$

Untuk memperoleh nilai Indeks Pelayanan PAI unit pelayanan digunakan pendekatan nilai ratarata tertimbang dengan rumus sebagai berikut:

Index $=\frac{\text { Total dari Nilai Persepesi Per Unsur }}{\text { Tutal unsur yang terisi }} \times$ Nilai penimbang
Untuk memudahkan interpretasi terhadap penilaian Indeks yaitu antara 25100 maka hasil penilaian tersebut di atas dikonversikan dengan nilai dasar 25, dengan rumus sebagai berikut: Indeks Pelayanan PAI Unit pelayanan x 2. Berdasarkan hasil penghitungan indeks kepuasan masyarakat, jumlah nilai dari setiap unit pelayanan diperoleh dari jumlah nilai ratarata setiap unsur pelayanan. Sedangkan nilai indeks komposit (gabungan) untuk setiap unit pelayanan, merupakan jumlah nilai ratarata dari setiap unsur pelayanan dikalikan dengan penimbang yang sama, yaitu 0,11 .

\section{PEMBAHASAN}

\section{Gambaran Umum Kota Palu}

Hamparan awan serta halimun yang lembut menyelimuti pegunungan dan perbukitan yang memagari Kota Palu, disertai rintik hujan yang masih kerap turun membasahi kota, walaupun tak lebat menandakan musim penghujan sudah mulai masuk di margin akhir. Keluar dari kabin pesawat yang membawa dari Kota Angin Mamiri, sekujur badan tiba-tiba terjebak di udara sejuk yang langsung menyelinap ke dalam ruas-ruas tulang dan mengantar ke rongga dada yang mengiringi setiap derap tarikan nafas. Sehingga citra kota yang sempat mengharu biru dunia maya/ninimasa dan media konvesional, bahwa kota ini tak aman dari gerilya kalangan teroris yang kerap melakukan kontak tembak dengan dengan aparat, terasa hilang dari memori.

Mengendarai taxi dari Bandara Mutiara SIS Al-Jufrie menuju hotel yang sebelumnya direkomendasikan teman-teman sekantor, sepanjang perjalanan yang tak terlalu jauh jaraknya menuju pusat kota, pandangan mata sangat termanjakan oleh pesona kota yang anggun, elegan dan pastinya masih ramah dengan penguninya, jalan-jalan utama pun masih relatif aman darimeminjam istilah Jean Couteau-"ruang borjuis berjalan" yang sejak beberapa tahun "berhasil" menganeksasi hingga menghegemoni warga di kotakota besar lainnya, dengan ritual kemacetannya.

"Kota multikultural yang eksotik," demikian kalimat yang terlontar dari salah seorang warga. memiliki relief pegunungan dan perbukitan, dataran lembah sekaligus pesisir pantai, semua keindahan alam berpadu, itulah lembah kota Palu. Berada di $2^{\circ} 22^{\prime}$ Lintang Utara dan $4^{\circ} 48^{\prime}$ Lintang Selatan serta $119^{\circ} 22^{\prime}$ dan $124^{\circ} 22^{\prime}$ Bujur Timur membuat Palu nyaris berada ditengah-tengah negeri Indonesia tercinta ini. Udaranya yang bersih 
dan tenang menambah kota ini terasa damai dan nyaman untuk dikunjungi. Maka, tak salah jika kota ini didapuk oleh Bung Karno sebagai "mutiara di khatulistiwa".

Laiknya kota-besar lainnya, kota Palu bermetamorfosa secara kebudayaan seiring dengan derap langkah perkembangan kota yang memantik hasrat orang untuk bermigrasi ke sini. Maka, tak ayal jika kemudian kota ini menjadi pertemuan beragam identitas. Tercatat dalam administrasi demografi kota, bahwa populasi kota Palu per 2016 telah menyentuh angka 368. 086 jiwa yang terbelah berdasar gender, meliputi laki-laki 185. 105 dan perempuan 182. 981 jiwa. Populasi ini mengalami pertumbuhan $1,62 \%$ dari tahun sebelumnya. Agregat populasi ini secara beragam berpijak pada alas etnis dengan latar belakang yang berbeda-beda, terdiri dari etnis Kaili yang mengklaim sebagai "etnis tempatan", etnis Jawa, etnis Bugis, Mandar, Makassar, Bali, Sunda, Arab, Manado, Minang dan lainnya.

Tak hanya identitas kultural, perbedaan latar belakang teologis pun ikut memperkaya nuansa, romansa serta konfigurasi sosial kota, kita tak akan kesulitan menemukan rumah-rumah ibadah yang menjadi penanda keragaman anutan agama warganya; Islam, Kristen, Katholik, Hindu dan Buddha. Agregat populasi tadi, terdiferensiasi secara persentase; Islam 84, 06 persen, Kristen 8, 16 persen, Katholik 2, 23 persen, agama Hindu 2, 0 persen, dan Buddha 3, 55 persen (Kota Palu dalam Angka 2016). Sementara eksistensi penganut agama Khonghuchu untuk konteks Kota Palu hingga kini belum teridentifikasi, dan berdasarkan hasil wawancara informan yang sehari-hari bertugas di PKUB Kanwil Kemenag Sulteng, MA/51 Tahun, secara gamblang menyatakan bahwa tidak ada penganut agama Khonghucu di Palu (wawancara di Palu, 19/07/2017).

Indeks Pembangunan Manusia (IPM) yang direngkuh Kota Palu tercatat saat berada di urutan ke-46 secara nasional berdasarkan Indeks Pembangunan Manusia (IPM) dalam upaya penurunan angka kemiskinan. Salah seorang informan mengklaim bahwa, urutan IPM tersebut menggambarkan bahwa adanya penurunan angka kemiskinan yang digalakkan oleh pemerintah setempat. Salah seorang informan mengakui kondisi ini bahwa, pembangunan manusia di Sulawesi Tengah terus mengalami kemajuan yang ditandai dengan meningkatnya nilai Indeks Pembangunan Manusia (IPM) periode 2010 - 2016.
Namun pembangunan manusia Sulawesi Tengah masih berstatus "sedang", yang disandang sejak 2010 (wawancara, 20/07/2017).

Sebelumnya ibu kota Provinsi Sulawesi Tengah itu berada di urutan ke-47 secara nasional, dalam penanggulangan kemiskinan daerah, sebelum diintervensi secara serius dengan berbagai program pemberdayaan. Saat ini, ujar dia, jumlah masyarakat miskin atau masyarakat berekonomi kelas menengah ke bawah mencapai 12.000-13.000 jiwa dari total jumlah penduduk Kota Palu kurang lebih 400.000 jiwa. Angka kemiskinan Kota Palu saat ini kurang lebih 6 persen dan terus diupayakan untuk berkurang dengan memaksimalkan strategi penanggulangan kemiskinan

Dalam skala nasional, Indeks Pembangunan Manusia (IPM/HDI) 2016, posisi Indonesia turun di peringkat ke-133 dari sebelumnya di posisi ke100 di antara 188 negara yang diukur oleh Program Pembangunan Perserikatan Bangsa-Bangsa (PBB). Jika dilihat dari arah IPM, Indonesia mencapai kemajuan bermakna sejak tahun 1990 untuk tiga komponen yang diukur, yaitu umur harapan hidup, pendidikan, dan pendapatan per kapita. Pendapatan nasional bruto naik 135,4 persen, angka harapan hidup naik 5,8 tahun, lama bersekolah rata-rata 4,6 tahun, dan harapan lama bersekolah meningkat 2,8 tahun dalam periode 1990-2015.

Pada domain pendidikan, dari sisi keterpenuhan lembaga/satuan pendidikan semua telah terpenuhi, mulai dari jenjang satuan pendidikan tingkat dasar, menengah dan tinggi, termasuk keberadaan satuan pendidikan vokasional. Jika focus pada satuan pendidikan yang menjadi sasaran riset; SMAN dan SMKN yang kini tersebar hingga ke sudut Kota Palu tercatat sebanyak 11 unit SMAN dan 15 unit SMA dengan status kelembagaan swasta, di Kota Palu juga terdapat 8 unit Sekolah Vokasional berstatus Negeri (SMKN) serta 17 unit sekolah vokasional (kejuruan) berstatus swasta.

Agregat satuan pendidikan menengah umum (SMAN) yang berjumlah 26 unit tadi, diisi oleh pendidik yang mengampu mata pelajaran yang beragam, sesuai latar belakang pendidikannya, dan sertifikasinya, tercatat ada sekitar 942 orang pendidik, yang mengasuh sekitar 10. 407 peserta didik, dengan rasio antara pendidik dan pesrta didik, 11. Sememtara di 25 sekolah kejuruan/ vokasional, diisi oleh agregat 857 pendidik, yang mengasuh sekitar 9.295 peserta didik yang tersebar di SMK negeri maupun swasta. 
Komitmen Global untuk Tujuan Pembangunan Berkelanjutan atau Sustainable Development Goals (SDGs).Terdapat 10 indikator yang sudah pada jalur yang benar, meskipun demikian masih dibutuhkan kajian-kajian yang komprehensif, untuk meliputi indikator-indikator percapaian target penurunan kemiskinan, kecukupan gizi dan kesehatan anak balita, tingkat partisipasi murni sekolah di tingkat SMA, infrastruktur dasar seperti: air minum, sanitasi, kualitas jalan dan rumah sederhana yang layak. Proyeksi pencapaian target-target ini menunjukkan bahwa upaya pemerintah dan masyarakat Kota Palu masih relatif sudah menuju on the track, termasuk juga daerah lain, untuk menyediakan pelayanan publik dan infrastruktur dasar.

Angka partisipasi murni (APM) maupun angka partisipasi kasar (APK) di sektor pendidikan, yang menjadi salah satu indikator ketercapaian SDGc diatas, untuk konteks Kota Palu tampak relatif baik dengan nilai APM 77, 58 dan APK 90, 43. Capaian nilai tampak berbeda dengan capaian APM dan APK SMA/SMK berbasis provinsi Sulawesi Tengah per tahun 2015 sebesar 63, 32, dan APK dengan nilai 82, 87. Terkait dengan harapan lama sekolah tercatat rata-rata 12,92 , dan secara riil rata-rata lama sekolah saat ini berada di kisaran 8,12 .

Aspek di atas penting dicermati, dalam upaya akselerasi (mempercepat) capaian Angka Partisipasi Kasar (APK) Pendidikan Menengah, yang jika tidak disiapkan sedari dini melalui program PMU (pendidikan menengah universal), maka target tersebut, yaitu APK 97\% (secara nasional) hanya diestimasikan baru tercapai di tahun 2040. Capaian tanpa skenario PMU itu, jika dikaitkan dengan bonus demografi (demografic dividen) dari dependency ratio yang makin kecil pada periode 2010 sampai 2040, yang secara alamiah kini direngkuh Indonesia, akan terlewatkan begitu saja tanpa makna.

Selain itu, APM, APK dan juga IPM Argumen ini dikuatkan laporan data Statistik World Bank 2011 dan The Global Competitiveness Report 20102011 menyebutkan, lama sekolah (baca: PMU) berkorelasi positif terhadap Indeks Pembangunan Manusia (IPM) atau Human Development Indeks (HDI). Lama sekolah pada laporan itu memiliki korelasi positif yang sangat tinggi dengan nilai PDB per kapita (koefisien korelasi 0,93). Demikian juga lama sekolah memiliki korelasi positif yang sangat tinggi dengan nilai Global Competitiveness Indeks GCI $(0,96)$.
Dimensi pendidikan, sebagai salah satu indicator untuk mengukur IPM setiap daerah. Untuk konteks Kota Palu dan Sulawesi Tengah secara makro, performa pendidikannya pun belum bisa dikategorikan menggembirakan, realitas ini diakui sendiri Kepala Dinas Pendidikan dan Kebudayaan Kota Palu, (www. antarasulteng. com)"Banyak siswa yang nilai UN-nya berada di bawah standar kelulusan yang ditetapkan Kementerian Pendidikan dan Kebudayaan (Kemendikbud)," katanya di Palu, Jumat. Bahkan, kata dia, ada nilai siswa yang hanya 1,0 jauh di bawah standar kelulusan, 5,5. Nilai ratarata UN kali ini jauh lebih rendah dari tahun-tahun sebelumnya.

Lainknya dua sisi mata uang, performa pendidik pun relative sama, jika dilihat dari nilai hasil UKG (Uji Kompetensi Guru) yang juga tergolong rendah, yang tengarai sebagai dampak dari minimnya kepedulian guru akan mutu sehingga kurang menjaga profesionalisme, minat baca rendah dan kemampuan mengakses dan menggunakan teknologi yang minim.Sehingga secara aggregate mempengaruhi performa pendidikan secara keseluruhan, sebagai tergambar pada Neraca Pendidikan Daerah (NPD) tahun 2015, untuk memberikan gambaran mutakhir tentang kondisi pendidikan pada satu daerah. Sulteng berada di peringkat 29 se Indonesia dengan 50,13 poin, satu tingkat di bawah Sulawesi Barat 50,15 poin dan di atas Papua Barat 49,13 poin (BPS, 2016).

\section{Pendidikan Agama di Kota Palu: Quo Vadis}

Mengacu pada program direktorat pendisdan secara makro (syumuliyah) juga berlaku di bimas lainnya terkait dengan layanan pendidikan agama-, secara spesifik program dan kegiatan di direktorat PAKIS, BIMAS Kristen, Katholik, Hindu dan Buddha yang salah tugas dan fungsinya adalah bergerak di ranah pendidikan agama. Maka, domain yang menjadi otoritas layanan lembaga tadi tak jauh dari aspek-aspek berikut: Pelayanan Pendidikan Agama adalah meningkatkan akses dan mutu pendidikan dasar-menengah (wajib belajar 12 tahun) yang meliputi: 1) Memperluas akses masyarakat untuk mendapatkan layanan pendidikan; 2) Meningkatkan penyediaan sarana prasarana pendidikan yang berkualitas; 3) Meningkatkan mutu peserta didik; 4) Meningkatkan jaminan mutu kelembagaan pendidikan; 5) Meningkatkan kurikulum dan pelaksanaannya; 6) Meningkatkan kualitas guru dan tenaga kependidikan. Materi layanan pendidikan agama pada bimas lainpun 
hampir sama, salah satunya misalnya tugas dan fungsi Direktorat pendidikan Hindu, terutama dari aspek pelayanan terdiri dari: 1) Bantuan beasiswa S1, S2, dan S3; 2) Bantuan sarana dan prasarana pendidikan; 3) Bantuan rehab/pembangunan gedung; 4) Bantuan operasional pendidikak; 5) Bantuan organisasi; 6) Bantuan tunjangan profesi; dan 7) Bantuan tunjangan lainnya

Ketersediaan pendidik pendidikan agamaIslam, Kristen, Katholik, Hindu Buddha di Kota Palu yang masih belum memenuhi standar minimum yang ditetapkan pemerintah dalam beberapa regulasi terkait. Untuk mata pelajaran agama Islam sendiri, hingga kini diampu sekitar 93 orang pendidik (pria), dan 263 pendidik (wanita) agregat 356 orang. Berkenaan dengan kualifikasi pendidikan kalangan pendidik PAI tersebut, terdiferensiasi ke dalam beberapa strata pendidikan, meliputi: $<$ S1 sebanyak 57 orang; yang telah berstatus $\mathrm{S} 1$ sebanyak 287; dan $>$ S2 agregat 22 pendidik PAI.

\section{Identitas Responden}

Sebagaimana dikemukakan sebelumnya, bahwa sumber data-kuantitatif- yang popular dengan istilah responden yang dikumpulkan melalui instrumen kuesioner, dalam ikhtiar untuk mengukur indeka pelayanan publik, dalam domain ini berkenaan dengan indeks layanan PAI di sekolah umum negeri (SMAN dan SMKN) yang secara konstitusional menjadi domain otoritas Kementerian Agama hingga kini. Responden pada riset ini terdiri dari kepala sekolah, guru agama (Islam, Kristen, Katholik, Hindu dan Buddha). Sementara Konghucu hingga riset dilakukan belum ditemukan data terkait eksistensi peserta didik, pendidik agama ini, dan itu diakui beberapa responden yang telah diwawancarai, termasuk pejabat FKUB Kanwil Kementerian Agama Provinsi Sulawesi Tengah.

Responden yang juga mendapatkan tugas tambahan sebagai kepala sekolah ini terdapat 18 orang (17 laki-laki dan 1 orang perempuan), dari 19 satuan pendidikan yang sejatinya menjadi sampel sasaran. Namun satu sekolah (SMKN 6) didiskualifikasi dengan pertimbangan tidak memenuhi syarat, sebab pendidik yang mengampu mata pelajaran agama semuanya masih berstatus tenaga honorer yang belum berurusan secara langsung dengan institusi Kemenag, keduanya hingga saat ini belum tersertifikasi, jadi praktis keduanya belum secara formal mendapatkan layanan Kementerian Agama.

Kategori Responden

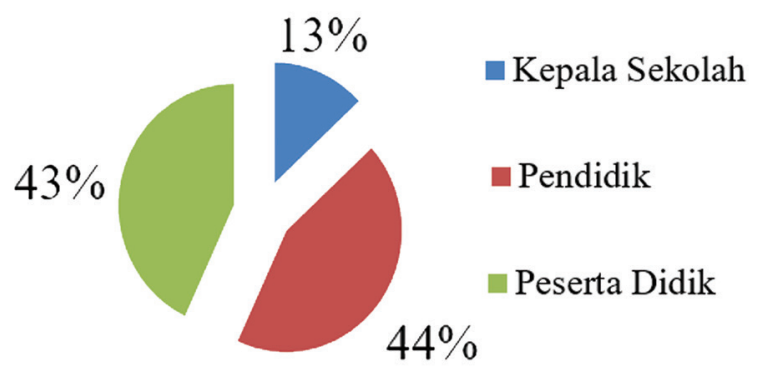

Tabel dia tas menyuguhkan data capaian strata pendidikan kalangan responden yang notabene mendapatkan tugas tambahan sebagai kepala sekolah, tampak sudah dominan yang mencapai jenjang strata dua (magister), dari sisi presentase sebanyak 72 persen (13 orang), dan selebihnya masih tertahan di strata satu (S1) dengan aggregate 28 persen ( 5 orang). Alibi yang dibangun relatif beragam, mulai dari alasan klasik, masalah biaya pendidikan, hingga belum adanya peluang yang diberikan hingga terbatasanya waktu di tengah kesibukan sebagai tenaga manajer di sekolah yang cukup menyita waktu. Identitas responden dari sisi jenis kelamin, responden yang terdiri dari kepala sekolah, pendidik dan peserta didik bisa diklasifikasi sebagai berikut: respoden laki-laki 71 orang (55 persen), dan responden perempuan sebanyak 62 orang (45 persen).

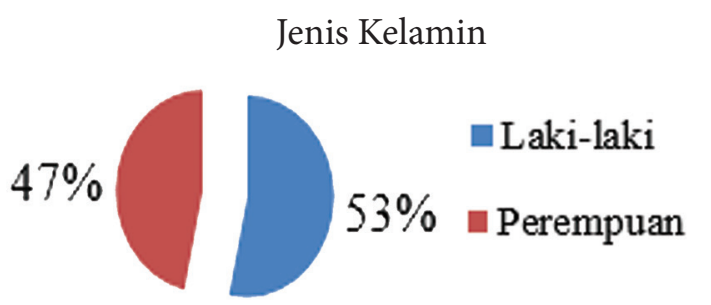

Selain jenis kelamin, identitas responden (guru) dari sisi pengalaman di dunia pendidikan, dengan melihat lamanya meraka menjalani profesi sebagai pendidik, yang dipastikan akan berimplikasi pada kualitas serta kompetensinya sebagai pendidik, dalam konteks ini tampak bahwa sangat variatif, di bawah 10 tahun atau satu dasawarsa sebanyak 15 orang, 11 sampai 20 tahun sebanyak 29 orang, guru yang telah mengabdi 21-30 tahun sebanyak 13 orang dan diatas 31 tahun keatas sebanyak 3 orang. 
Pengalaman Mengajar Responden (Pendidik)

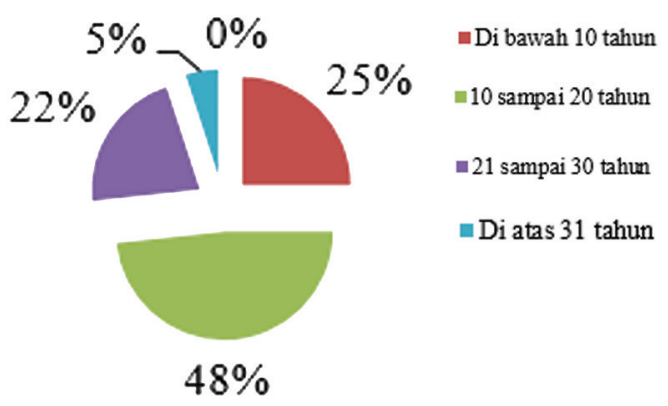

Melalui tabel ini, tampak bahwa guru-guru agama pada sekolah umum (SMAN dan SMKN) di Kota Palu telah mengampu mata pelajaran ini mulai dari 1 sampai satu dasawarsa, sebanyak 25 persen, yang memiliki pengalaman mengajar selama 10 sampai dua dasawarsa sebanyak 48 persen dan ini yang paling dominan untuk saat ini, dan guru yang telah berkhidmat sepanjang tiga dasawarsa, sebanyak 22 persen, bahkan ada 5 persen yang telah melampaui tiga dasawarsa, tepatnya 32 tahun keatas.

Peserta didik dari berbagai agama pun menjadi sampel sasaran pada penelitian ini, yang diasumsikan sebagai elemen yang-langsung maupun tidak langsung-mendapatkan layanan Kementerian Agama, sebagai stakeholder atau penyedia layanan yang berkaitan dengan pendidikan agama di sekolah. Setidaknya, dari kuesioner yang masuk dan layak dianalisis lebih lanjut, terdapat 59 peserta didik yang menjadi sumber data primer, yang dapat diklasifikasikan berbasis pada agama yang dianut (pendidikan agama yang diterima). Peserta didik yang menerima layanan PAI sebanyak 36 responden, penerima layanan PAK 17 orang, layanan pendidikan agama Katholik 3 orang, agama Buddha 1 orang dan Hindu 3 tiga orang.

Agama Peserta Didik (Responden)

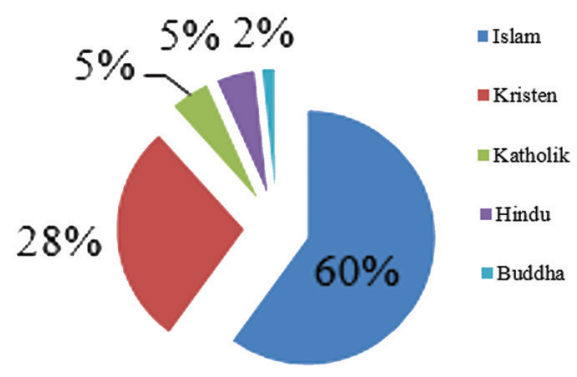

Responden dari kalangan peserta didik didominasi mereka yang selama ini menerima layanan pendidikan agama Islam dengan aggregate 60 persen, Kristen 28 persen, Katholik 5 persen, Hindu juga 5 persen, dan peserta didik yang menerima layanan pendidikan agama Buddha yang menjadi responden penelitian ini sebanyak 2 persen.

\section{Indeks Layanan Pendidikan Agama}

Sebagaimana didedahkan pada bab sebelumnya, bahwa penelitian ini sepenuhnya mengacu pada Permen PAN/RB yang telah mengatur sejatinya penelitian indeks layanan publik itu lakukan oleh setiap Kementerian dan Lembaga untuk mengukur tingkat efektivitas yang terejawantah dalam tingkat kepuasan publik terhadap layanan yang telah diberikan. Setidaknya, ada sembulan tahapan yang perlu dipenuhi dalam kerangkan pelayanan publik tersebut, meliputi: persyaratan; prosedur; waktu pelayanan; biaya/tarif; spesifikasi layanan; kompetensi pemberi layanan; perilaku pelaksana layanan; maklumat pelayanan; saran dan masukan.

Relevansinya dengan layanan pendidikan agama yang menjadi kewajiban konstitusional Kementerian Agama, terdapat beberapa materi layanan, baik yang berbentuk tangible maupun intangible yang sejatinya diberikan, terdiri dari: pendidik, pengawas, kompensasi/tunjangan profesi yang populer dengan tunjangan sertifikasi, sarana dan prasarana pembelajaran, kurukulum yang memuat pendidikan agama.

Dari hasil analisis secara kuantitatif dengan memanfaatkan aplikasi EXEL terhadap kuesioner yang telah diisi kalangan responden, berkaitan dengan beberapa variabel dan indikatornya masingmasing, dalam hal ini materi layanan pendidikan agama yang berikan oleh pihak Kementerian Agama dengan mengacu pada tahapan yang diafirmasikan Menpan RB (tentu dengan beberapa penyesuaian sesuai konteks layanannya). Mengapa konteks, sebab ada beberapa yang perlu dicermati untuk digunakan secara kaku, misalnya biaya/tarif, ternyata rata-rata responden menyatakan bahwa layanan yang selama ini diberikan justru tidak membutuhkan biaya/tarif, sebagaimana lazimya, bahwa setiap layanan yang diberikan, butuh biaya. Tapi layanan yang diberikan Kementerian Agama, justru bebas biaya/tarif. 
Grafik 1. Nilai Indeks Masing-Masing Unit Layanan PAI

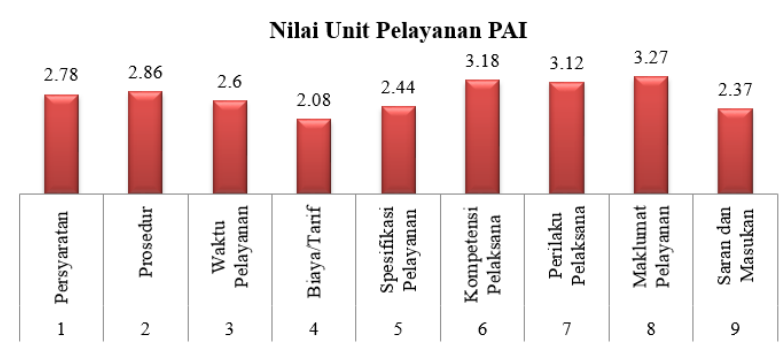

Sumber: Hasil Olah Data Kuantitatif, 2017.

Nilai rata-rata IKM2,72 jika dikonversi, berarti tepat berada di gradasi nilai 68.63, merupakan hasil pengukuran komposit unit-unit pelayanan yang selama ini diberikan pihak Kementerian Agama sebagai provider (penyedia layanan) pendidikan agama kepada satuan pendidikan umum, dengan beberapa materi layanan sebagaimana yang tertuang dalam Rencana Strategis Pendidikan Islam kementerian Agama tahun 2015-2019, sebagaimana dikemukakan pada bab I sebelumnya, terdiri dari rekruitmen pendidik yang ditugaskan di satuan pendidikan menengah umum-untuk konteks penelitian ini SMAN dan SMKN-dengan mengampu mata pelajaran Pendidikan Agama (Islam, Kristen, Katholik, Hindu dan Buddha). Tak hanya terbatas pada rekruitmen pendidik, Kementerian Agama juga member layanan dari sisi sarana dan prasarana, sumber-sumber belajar berupa buku teks pendidikan agama (pegangan pendidik dan tenaga kependidikan), perangkat pembelajaran (manual maupun IT) dan terakhir kurikulum pendidikan agama yang sejatinya berada dalam otoritas Kementerian Agama.

Jika dirunut materi layanan yang diberikan Kementerian Agama terkait pembelajaran mata pelajaran agama pada pendidikan menengah umum (SMAN dan SMKN) sebagaimana dipaparkan diatas, dan relevansinya dengan persepsi responden (kepala sekolah, pendidik dan peserta didik) terhadap pelayanan yang selama ini diberikan pihak Kementerian Agama sebagai provider, maka tampak bahwa rata-rata persepsi responden "jatuh" pada kategori puas dengan mutu layanan yang $B$ pada gradasi respon.

\section{Pelayanan Pendidikan Agama di Sekolah Umum: Quo Vadis}

Mengacu pada analisis data statistik deskriptif di atas, maka pada variable rekruitmen dan SDM pendidik yang mengampu mata pelajaran agama (Islam, Kristen, Katholik, Hindu dan Buddha) pada satuan pendidikan menengah umum di Kota Palu, nilai indeks kepuasan publik terkait dengan variabel ini, diperoleh 70.5 poin yang jika dikonversi maka terkategori puas (B). Meskipun nilai indeks menggembirakan, itu tidak berarti tidak menyisakan problem, yang membutuhkan solusi konstruktif dari pihak pengambil kebijakan (decision makers), terutama pihak Kementerian Agama, tentu dengan tetap melalui koordinasi Kementerian Pendidikan dan Kebudayaan.

Di titik ini, yang paling krusial adalah rekruitmen pendidikan melalui dua pintu (double windows), terdapat pendidik yang mengampu mata pelajaran agama yang direkrut Dinas Pendidikan dan Kebudayaan dan untuk konteks Kota Palu dan Provinsi Sulawesi Tengah secara makro (syumuliyah), melalui jalur ini yang paling banyak, salah seorang responden mengestimasikan sekitar 90 persen, dan selebihnya, atau sekitar 10 persen, rekruitmen melalui Kementerian Agama. Responden yang bertugas di SMKN 5 dan koleganya menyebut dengan nada satir, bahwa dengan pola pengelolaan guru agama saat ini, ibaratnya kamu memiliki dua ibu, satu ibu kandung yang satunya lagi ibu tiri". Serba membingungkan.

Untuk menjustifikasi pendapatnya di atas, responden (wawancara, 13/08/2017) tadi lalu merujuk pada Peraturan Pemerintah Nomor 55 Tahun 2007 tentang Pendidikan Agama dan Pendidikan Keagamaan disebutkan bahwa persoalan pendidikan agama, tentunya termasuk Islam di dalamnya, menjadi kewenangan Kementerian Agama. Kementerian Agama merupakan lembaga yang paling otoritatif dalam penyelenggaraan PAI ini. Namun demikian, di dalam PP itu juga, terutama pada pasal 6 ayat (1), Pemerintah Daerah memungkinkan untuk membantu dalam penyelenggaraan pendidikan agama, termasuk dalam pengangkatan dan pendanaannya.

Pola rekruitmen melalui dua pintu ini, laksana bola salju yang menggelinding, telah membuncahkan banyak masalah yang bermuara pada kebingunagan pada pihak pendidik, pengawas, tak terkecuali kepala sekolah. Maka, tak heran, jika harapan, atau tepatnya tuntutn mereka agar pola rekruitmen yang selama ini berjalan agar direvisi, menemukan konsensus. Mereka menyarankan agar rekruitmen guru agama sejatinya melalui satu pintu saja (one stop recruitment) melalui Kementerian Agama. Menurut salah seorang responden (wawancara 14/08/2017), yang sehari-hari bertugas di Kanwil Kemenag Sulteng, bahwa sebenarnya 
wacana rekruitmen guru agama melalui satu pintu (one stop system) telah digelidingkan sejak tahun lalu (2016), namum hingga kini wacana tersebut belum diangkat ke tingkat kebijakan".

Keterpenuhan guru-guru agama, juga menjadi persoalan yang ikut menggenapi problem tadi, persepsi responden (kepala sekolah) berkenaan dengan keterpenuhan jumlah guru agama di sekolah yang mereka kelola, menemukan pembenarannya, terbukti layanan ini hanya terkategori secara rata-rata 2.16 (dengan mutu layanan cukup puas). Sebab memang, secara factual, masih terdapat beberapa satuan pendidikan yang belum sesuai rasio antara guru agama dan peserta didik, keterpenuhan guru masih di bawah quota yang sejatinya terpenuhi. Tengok misalnya di SMKN 6 yang terletak di Mamboro, saat ini mendidik sekitar 900 peserta didik sekitar 12 kelas, mereka saat ini hanya mengandalkan layanan pendidikan agama Islam dari dua orang tenaga honorer, keduanya perempuan. Status keduanya yang masih berstatus tenaga honorer, bagi wakil kepala sekolah bidang kesiswaan, dan keduanya ibu rumah tangga menjadikan kita terkendala untuk mengharapkan partisipasi aktif mereka. Banyak kegiatan keagamaan di sekolah yang tidak bisa mereka sepenuhnya untuk ikut terlibat secara aktif.

Apalagi kondisi saat ini, lanjut Muhaimin (wawancara, 16/08/2017), pengaruh eksternal sangat mengancam mentalitas, karakter dan kepribadian siswa, kondisi ini meniscayakan kehadiran guru-guru agama yang memiliki komitmen tinggi untuk mendidik, kami hanya bisa mengharapkan komitmen itu dari guru-guru dengan status PNS, tapi hingga kini semuanya masih tinggal harapan. Padahal, kami sangat proaktif mengajukan permohonan, bahkan hampir tiap bulan sesuai format kebutuhan guru, baik di Dapodik maupun di DKG (Daftar Kebutuhan Guru), dan di situ kelihatan kebutuhan masingmasing satuan pendidikan, namun hingga kini belum direalisasikan juga.

Kondisi pada guru agama Kristen, Katholik, Hindu dan Buddha, ternyata lebih krusial lagi, sebab di beberapa sekolah guru agama, terutama yang bertatus PNS, masih merupakan "barang mewah". Praktis, kita hanya akan menemukan sebagian kecil sekolah saja yang telah memiliki guru agama dengan status PNS. Itu biasanya hanya ditemukan di pusat kota saja. Seperti di SMAN 1, SMAN 2, SMKN 1, SMKN 1, dan sekolah di sekitarnya. Tapi ketika kita sedikit bergeser ke kawasan penggiran kota, maka sulit menemukan guru agama diluar agama Islam yang bertugas di sekolah-sekolah tersebut, tengoklah misalnya, SMAN 9 di Pantoloan, yang terkenal sebagai wilayah pelabuhan ini, menurut kepala sekolahnya (wawancara, 15/08/2017); "untuk melayani peserta didik yang beragama Kristen di sekolah ini, mereka berinisitif untuk memberdayakan Kepala Tata Usaha Sekolahberagama Kristen-untuk mengampu mata pelajaran agama Kristen (PAK) di sekolah ini."Setali tiga uang dengan problem yang dialami SMKN 8, hingga kini sekolah ini pun belum memiliki guru agama Kristen, pihak sekolah berinisiatif untuk "meminjam tenaga" guru olah raga untuk mengampu mata pelajaran agama Kristen. Jadi, keterpenuhan guru PAK di Kota Palu, masih jauh dari kata memadai. Nah, untuk menyiasati kendala tersebut, selama ini, peserta didik di arahkan ke gereja masing-masing untuk mendapatkan materi PAK yang kerap diampu para pendeta. Kami membuka kerjasama dengan pihak gereja, dengan mengedepankan kebutuhan peserta didik akan pendidikan agama.

Meskipun tidak bisa dinafikan juga, bahwa sebagian satuan pendidikan telah memenuhi layanan minimal dengan keberadaan guru-guru agama, tapi itu masih terbatas pada beberapa sekolah saja. Ambil contoh di SMAN 1 yang mememiliki jumlah peserta didik sampai 1520 orang yang dilayani guru-guru agama (PNS dan honorer) yang memadai, baik Islam, Kristen, Katholik, Hindu maupun Buddha.

Maka, tepat kiranya, jika beberapa kepala sekolah mengemukakan bahwa, keterpenuhan guru agama, khususnya agama non Islam di Kota Palu, dan Sulawesi Tengah pada umumnya, masih jauh dari memadai, maka, wajar jika mereka mengusulkan agar di sekolah mereka dipenuhi kebutuhan guru agama, khususnya, Hindu dan Kristen, sebagaimana saran Kepala SMKN 8, Djalal Nani. Aspirasi yang senada juga diusulkan Abd Kadir, Kepala SMAN Model, dengan pernyataan lengkap, "sangat perlu penambahan guru agama, khususnya di sekolah kami."

Selain itu, buku teks-pegangan guru maupun peserta didik-pendidikan agama yang sejatinya diadakan Kementerian Agama pun masih digolongkan sebagai barang mewah di sekolah hingga hari ini. Selama ini, pihak sekolah melakukan pengadaan langsung dengan menggunakan dana BOS, yang dicetak oleh kalangan tertentu, dan melihat logonya, buku agama tersebut menggunakan logo Kementerian 
Pendidikan dan Kebudayaan. Terang saja, dengan bernasnya, Budiono, Wakasek Kurikulum SMAN 1, menyatakan, "bahan ajar yang digunakan oleh guru mata pelajaran agama berasal dari Kemendikbud, bukan dari Kementerian Agama, ujarnya tandas. Segenap guru dan kepala sekolah ijma mengenai ketiadaan sumber-sumber belajar agama, termasuk buku teks dari Kementerian Agama. Bu Syarifah, Guru PAI SMAN 4, dengan tandas mengemukakan bahwa teks PAI tidak pernah ada, dan tidak pernah dilakukan pengadaan, buku PAI kami dari Diknas punya, ujarnya.

Sebab, bagi Masrun, dan guru agama lain, tentunya, untuk meningkatkan kompetensi siswa, maka sangat dibutuhkan sember belajar, dan fasilitasnya yang memadai, misalnya buku paket, dan buku penunjang lainnya. (wawancara 21/08/2017). Keluhan yang sama juga dating dari Aminuddin, Guru PAI SMKN 6, tidak ada buku teks PAI (pegangan guru maupun siswa) dari Kemenag (wawancara, 13/08/2017). Setali tiga uang dengan Sartono, guru agama Hindu, "buku-buku pelajaran Agama Hindu, khsususnya K 13, sangat sulit kami peroleh". Djalal Nani, Kepala SMKN 8 mengusulkan agar guru-guru agama dibantu dengan buku-buku pegangan, sebaiknya menjadi kewenangan Kemenag yang mengerti betul materi pendidikan agama, karena itu memang ranahnya. Untuk memenuhi standar isi pembelajaran PAI, guru-guru agama berinisiatif sendiri untuk mencari sumber-sumber belajar lainnya, untuk pengayaan.

Masalah yang menggelayuti pengelolaan guru agama, semakin besar dengan minimnya penguatan kapasitas serta kompetensi mereka, yang sejatinya ditunaikan. Tak ayal, jika persoalan ini cukup mengemuka di sesi wawancara dengan para kepala sekolah dan guru agama. Tak hanya berimplikasi negatif pada pendidik, pengelolaan guru agama secara dual sistem (melalui Kementerian Agama dan Dinas Pendidikan dan Kebudyaan juga beresonansi pada optimalisasi supervise yang dilakukan para pengawas yang secara keseluruhan pengawai Kementerian Agama.

Proses supervisi yang kerap terkendala oleh ego sektoral, masing-masing lembaga, juga menyeruak seiring dengan kebijakan rekruitmen dua pintu di atas. Salah seorang pengawas mengeluhkan proses komunikasi dan supervise yang kerap terkendala, "banyak masalah kalau berhubungan dengan guru-guru PAI diknas", mereka kerap mengaitkan alabinya pada lembaga induknya. Berbeda dengan guru-guru PAI kemenag, karena sama-sama di bawah satu lembaga sehingga proses komunikasi, koordinasi dan supervise lebih mudah, dan nyaris tak mengalami kendala.

Tengok misalnya, proses sertifikasi yang sejatinya melalui pengawas PAI, di titik ini sering dijumpai masalah di lapangan terutama sinkronisasi, terutama diawal kebijakan sertifikasi, karena masing-masing lembaga secara internal memiliki kebijakan berkenaan dengan proses serta persyaratan. Di diknas lebih sederhana, hanya bermodalkan selembar berkas, lalu ditanda tangani pengawas, maka tunjangan sertifikasi pun otomatis terbayarkan. Sementara di Kementerian Agama tidak cukup dengan itu, ditekankan kepada guruguru agama, agara berkas-berkasnya dilengkapi; seperti agenda harian, jurnal, biodata dan lain-lain. Dan perbedaan ini, menurut responden merupakan masalah tersendiri yang perlu mendapat perhatian pemerintah untuk disinkronkan.

\section{PENUTUP}

Berdasarkan hasil analisis data dengan menganalisis secara statistik deskriptif untuk mengukur indeks pelayanan pendidikan agama (Islam, Kristen, Katholik, Hindu dan Buddha) pada satuan pendidikan menengah umum negeri, tepatnya pada SMAN dan SMKN sampel sasaran di Kota Palu, Sulawesi Tengah. Relevansinya dengan Pembelajaran Pendidikan Agama, Kementerian Agama sejatinya sebagai provider layanan, baik layanan berupa rekruitmen guru, penyediaan sarana dan prasarana, buku teks pegangan guru maupun siswa, dan sumber belajar lainnya, perangkat pembelajaran dan juga kurikulum PAI. Penelitian ini memanfaatkan metode kuantitatif dengan fokus pada pengukuran berupa indeks, untuk mengukur mutu layanan pada sembilan unit layanan yang semestinya dipenuhi kementerian Agama. Terdiri dari: persyaratan; prosedur; mutu layanan; biaya; spesifikasi layanan; kompetensi pelaksana; perilaku pelaksana; maklumat pelayanan, dan; saran serta masukan. Hasil penelitian menunjukkan, bawah tingkat/indeks layanan pendidikan agama di Kota Palu berada pada kategori puas, dengan nilai rata-rata unit layanan atau IKM sebesar 2,72, jika dikonversi dalam gradasi nilai, maka berada di nilai 68,63. IKM dengan mutu layanan B (puas), masih menyisakan masalah yang perlu dicarikan solusi konstruktif, terutama pada aspek: rekruitmen guru, pengadaan buku teks dan sumber belajar lainnya, penguatan kapasitas guru melalui pendidikan dan latihan, bimbingan teknis, dan pemenuhan 
sarana dan prasarana yang terkait langsung dengan pembelajaran agama di sekolah-sekolah menengah umum.

\section{UCAPAN TERIMA KASIH}

Penulis menyadari sepenuhnya bahwa, tulisan ini tidak akan hadir di hadapan sidang pembaca yang budiman, tanpa keterlibatan, bantuan dan sikap altruisme beberapa pihak, Kabid Pakis, Kepala Kemenag Kota Palu, KGG-MGMP, pengawas, kalangan responden yang telah membukakan akses untuk mendapatkan data dan informasi berkenaan dengan topik riset ini. Sebagai apresiasi penuh, penulis menghaturkan banyak terima kasih dan iringin doa semoga hidup semakin berberkah dan sukses selalu.

\section{DAFTAR PUSTAKA}

Al-Abrashy, Muhammad Athiyah, 1987. Al-Tarbiyyah AlIslamiyyah, diterj. Bustami A. Gani: Dasar-Dasar Pokok Pendidikan Islam, Jakarta: Bulan Bintang.

Al-Ashfahani, Al-Raghib, 2005. Al-Mufradat fi Gharibil Quran, Beirut-Libanon: Daarul Maarif.

Badan Litbang dan Diklat Kementerian Agama RI, 2015. Rencana Strategis 2015-2019

Badan Pusat Statistik, Kota Palu dalam Angka 2016

Kementerian Aparatur Negara dan RB, 2014. Peraturan Menteri Negara Aparatur Negara dan Reformasi Birokrasi Nomor 16 tahun 2016 tentang Pedoman Indeks Kepuasan Masyarakat
Kerlinger, Fred. N, 2003. Foundation of Behavioral Research, diterj. Landung R. Simatupang: AsazAsas Penelitian Bahavioral, Yogyakarta: UGM Press.

Mastuhu, 2003. Menata Ulang Pemikiran Sistem Pendidikan Nasional, Yogyakarta: Safiria Insania Press

Morissan, 2014. Metode Penelitian Survey, Jakarta: Kencana Prenadamedia Group

Al-Nahlawi, Abdurrahman,.1990. Ushul fi Tarbiyat alIslamiyyat wa Asalibuha diterj. Herry Nur Ali: Prinsip-Prinsip dan Metode Pendidikan Islam, Semarang: CV. Diponegoro.

Prasojo, Eko, 2009. Reformasi Kedua: Melanjutkan Estafet Reformasi, Jakarta: Salemba Humanika

Santoso, Pandji, 2009. Administrasi Publik: Teori dan Aplikasi Good Governance, Bandung: PT Refika Aditama

Sevilla, Consuelo, et.al, 1993. An Introduction to Research Methods, diterj. Alimuddin Tuwu: Pengantar Metode Penelitian, Jakarta: UI Press

Sinambela, Lijan Poltak, et. al, 2008. Reformasi Pelayanan Publik: Teori, Kebijakan dan Implementasi, Jakarta: PT Bumi Aksara

Sofian Effendi, et.al. 1989. Metode Penelitian Survey, Jakarta: PT Pustaka LP3ES

Supriyanto, Budi, 2009. Manajemen Pemerintahan, Jakarta: CV Media Brilian

Syihab, Quraish, 2002. Tafsir Al-Misbah, Volume. I, Jakarta: Lentera Hati

Syukri, Agus Fanar, 2009. Standar Pelayanan Publik Pemda Berdasarkan ISO 9001/IWA-4, Banten: IQRA 